\title{
Penerapan Asesmen Kinerja Pada Kegiatan Praktikum Biologi Untuk Meningkatkan Keterampilan Proses Sains dan Hasil Belajar Kognitif Siswa
}

\author{
${ }^{\star 1}$ Purnawati, ${ }^{1}$ Any Fatmawati, ${ }^{1}$ Safnowandi, ${ }^{2}$ Siti Murdiyah \\ ${ }_{1}^{1}$ Program Studi Pendidikan Biologi, FSTT, Universitas Pendidikan Mandalika, Jl. Pemuda No. 59A \\ Mataram 83125, Indonesia \\ Program Studi Pendidikan Biologi, FKIP, Universitas Jember, JI. Kalimantan Tegalboto No.37, \\ Jember 68121, Indonesia \\ *Correspondence e-mail: purnawati@gmail.com
}

\begin{abstract}
Abstrak: Tujuan dari penelitian ini adalah untuk mendeskripsikan penerapan asesmen kinerja dalam meningkatkan keterampilan proses sains dan hasil belajar kognitif siswa kelas VII MTs Darul Hikmah Darek. Subjek penelitian ini adalah 20 siswa kelas VII MTs Darul Hikmah Darek. Penelitian ini merupakan penelitian tindakan kelas (PTK) dengan menggunakan dua siklus. Data keterampilan proses sains dikumpulkan menggunakan instrument lembar observasi, sedangkan hasil belajar kognitif siswa dikumpulkan menggunakan instrument tes dengan 20 item soal. Keterlaksanaan pembelajaran juga diukur dalam penelitian ini menggunakan lembar observasi keterlaksanaan (RPP). Data penelitianian dianalisis secara deskriptif. Hasil penelitian menunjukkan (1) keterlaksanaan RPP pada siklus I mencapai $68 \%$ dengan kategori baik, sedangkan pada siklus II mencapai $100 \%$ dengan kategori sangat baik; (2) keterampilan proses sains pada siklus I mencapai 55\% dengan kategori cukup tinggi, dan pada siklus II mencapai 75\% dengan kategori tinggi; dan (3) skor rata-rata hasil belajar kognitif siswa pada siklus I mencapai 66 dengan ketuntasan klasikal sebesar 40\%, sedangkan siklus II mencapai 77 dengan ketuntasan klasikal sebesar 90\%. Berdasarkan hasil penelitian dapat disimpulkan bahwa penerapan asesmen kinerja dapat meningkatkan keterampilan proses sains dan hasil belajar kognitif siswa pada kelas VII MTs Darul Hikmah Darek.
\end{abstract}

Kata kunci: Asesmen Kinerja, Keterampilan Proses Sains; Hasil Belajar Kognitif

\section{The Implementation of Performance Assessment in Biology Practicum Activities to Improve Students' Science Process Skills and Cognitive Learning Outcomes}

\begin{abstract}
The purpose of this study was to describe the implementation of performance assessment in improving science process skills and cognitive learning outcomes of seventh grade students of MTs Darul Hikmah Darek. The subjects of this study were 20 grade VII students of MTs Darul Hikmah Darek. This research is a classroom action research (CAR) using two cycles. Science process skills data were collected using an observation sheet instrument, while students' cognitive learning outcomes were collected using a test instrument with 20 items of questions. The implementation of learning was also measured in this study using the implementation observation sheet (RPP). The researcch data were analyzed descriptively. The results showed (1) the implementation of the lesson plans in the first cycle reached $68 \%$ in the good category, while in the second cycle it reached $100 \%$ in the very good category; (2) science process skills in the first cycle reached 55\% in the fairly high category, and in the second cycle it reached $75 \%$ in the high category; and (3) the average score of students' cognitive learning outcomes in the first cycle reached 66 with classical completeness of $40 \%$, while the second cycle reached 77 with classical completeness of $90 \%$. Based on the results of the study, it can be concluded that the implementation of performance assessments can improve science process skills and cognitive learning outcomes of students in class VII MTs Darul Hikmah Darek.
\end{abstract}

Keywords: Performance assessment, Scienc process skills, Cognitive learning outcomes

How to Cite: Purnawati, P., Fatmawati, A., Safnowandi, S., \& Murdiyah, S. (2020). Penerapan Asesmen Kinerja Pada Kegiatan Praktikum Biologi Untuk Meningkatkan Keterampilan Proses Sains dan Hasil Belajar Kognitif Siswa. Empiricism Journal, 1(1), 20-27. https://doi.org/10.36312/ej.v1i1.603

https://doi.org/10.36312/ej.v1i1.603

Copyright@ 2020, Purnawati et al This is an open-access article under the CC-BY-SA License. (c) (1) (2)

\section{PENDAHULUAN}

Pendidikan Indonesia terus ditingkatkan sejalan dengan perkembangan era globalisasi. Hasil studi PISA (Program for International Student Assessment) pada tahun 2011 
menunjukkan peringkat Indonesia hanya menduduki 10 besar terbawah dari 65 negara, sedangkan pada tahun 2015 Indonesia berada pada urutan 69 dari 75 negara di dunia (OCED, 2016). Sejalan dengan hasil studi PISA, hasil studi TIMSS (Trends in International Mathematics and Science Study) tahun 2011 menunjukkan siswa Indonesia berada pada ranking yang rendah dalam kemampuan (1) memahami informasi yang komplek, (2) teori, analisis dan penyelesaian masalah, (3) pemakaian alat, prosedur dan penyelesaian masalah dan (4) melakukan investigasi (Kemendikbud, 2013; Martin dkk., 2012). Hasil studi tersebut menunjukkan perlu perubahan orientasi kurikulum dengan tidak membebani peserta didik dengan konten namun pada aspek kemampuan esensial yang diperlukan semua warga negara untuk berperanserta dalam membangun negara pada masa mendatang (Muhali, 2019) seperti keterampilan proses sains (Verawati dkk., 2014). Kecenderungan yang dilakukan oleh guru dalam pembelajaran sains yang hanya mempelajari sains sebagai produk (Setyowati dkk., 2011) semakin memperkuat pentingnya keterampilan proses sains sebagai komponen yang harus diperhatikan dalam pembelajaran sains termasuk biologi.

Keterampilan proses sains merupakan langkah awal untuk membelajarkan keterampilan berpikir tingkat tinggi bagi siswa (Nur, 2011). Keterampilan proses sains merupakan keterampilan dasar yang memfasilitasi pembelajaran siswa untuk aktif, bertanggung jawab, menigkatkan pemahaman siswa terhadap metode ilmiah menggunakan keterampilan berpikir rasional yang efektif dan efisien untuk mencapai suatu hasil tertentu (Gürses dkk., 2015). Sejalan dengan pendapat tersebut, keterampilan proses sains disinyalir membantu siswa untuk mengembangkan rasa tanggung jawab dalam pembelajaran serta meningkatkan kesadaran akan pentingnya metode ilmiah dalam pembelajaran sains. Keterampilan proses sains bertujuan untuk melatih siswa lebih aktif dalam memahami serta menguasai rangkaian kegiatan yang dilakukan seperti mengamati, klasifikasi, intepretasi, prediksi, berhipotesis, merencanakan percobaan, dan berkomunikasi (Asy'ari dkk., 2019; Rustaman, 2005), yang seharusnya dikuasai dan menjadi perhatian guru dalam pembelajaran sains di kelas (Nur, 2011).

Selain perhatian terhadap komponen keterampilan proses, penilaian terhadap produk pembelajaran juga penting dilakukan (Am, 2018). Penilaian dalam pendidikan merupakan proses mangukur kemampuan atau keterampilan siswa dalam mencapai tujuan pembelajaran yang telah ditetapkan (Mulyasa \& Mukhlis, 2007). Penilaian berfungsi untuk mengetahui seberapa banyak indikator kompetensi dasar tercapai, menilai kebutuhan individual, kebutuhan pembelajaran, membantu dan mendorong siswa memiliki motivasi dalam belajar, membantu dan menolong guru mengajar lebih baik, menentukan strategi pembelajaran yang sesuai, dan sebagai upaya meningkatkan kualitas pendidikan (Amrulloh, 2015). Hasil penelitian menunjukkan penilaian berperan penting dalam memperkuat penilaian otentik dalam ranah pengetahuan, sikap, dan keterampilan (Hadiana, 2015).

Berdasarkan uraian tersebut, penilaian merupakan salah satu factor yang dapat meningkatkan prestasi belajar siswa khususnya pada pelajaran biologi dan mata pelajaran yang lainnya, karena penilaian dalam pembelajaran memiliki jenis yang bervariasi, di mana dalam penilaian bertolak dari suatu pandangan bahwa setiap peserta didik, memiliki potensi yang berbeda-beda, oleh karena itu penelitian menyajikan model penilaian alternatif untuk meningkatkan aktivitas belajar siswa melalui penilaian kinerja. Hal-hal yang diuraikan sebelumnya kurang diperhatikan oleh sebagian guru, dan informasi tentang kemajuan kinerja dan keaktifan siswa tidak dapat dilihat secara keseluruhan. Untuk mengetahui kemajuan kinerja dan keaktifan siswa secara keseluruhan, dapat dilaksanakan melelui alternatif penilaian kinerja dan keaktifan siswa yaitu asesmen kinerja (asessment performance). Asesmen kinerja atau penilain kinerja merupakan salah satu penilaian dimana guru mengamati dan membuat pertimbangan tentang demonstrasi siswa dalam hal kecakapan dan menghasilkan suatu produk (Widodo dkk., 2010). Penelitian ini bertujuan untuk mendeskripsikan penerapan asesmen kinerja dalam meningkatkan keterampilan proses sains dan hasil belajar kognitif siswa kelas VII MTs Darul Hikmah Darek. Keterampilan proses sains yang diamati dalam penelitian ini merupakan keterampilan proses sains dasar yang meliputi observasi, komparassi, klasifikasi, mengukur, dan komunikasi (Asy’ari \& Fitriani, 2017). 


\section{METODE}

Jenis penelitian yang digunakan adalah Penelitian Tindakan Kelas (PTK). Penilaian Tindakan Kelas (Classroom Action Research) yang merupakan suatu pengamatan terhadap kegiatan yang sengaja dimunculkan dan terjadi dalam kelas. Pendekatan yang digunakan dalam penelitian ini adalah pendekatan kualitatif dan pendekatan kuantitatif. Penelitian ini dilaksanakan di MTs Darul Hikamah Darek Tahun pelajaran 2015/2016 dengan pokok bahasan ekosistem dan komponennya, dan pentingnya keanekaragaman bagi mahkluk hidup. Penelitian ini melibatkan 20 siswa pada kelas VII A. Secara singkat Rancangan Pelaksanaan Penelitian Tindakan Kelas (PTK) disajikan pada Gambar 1.

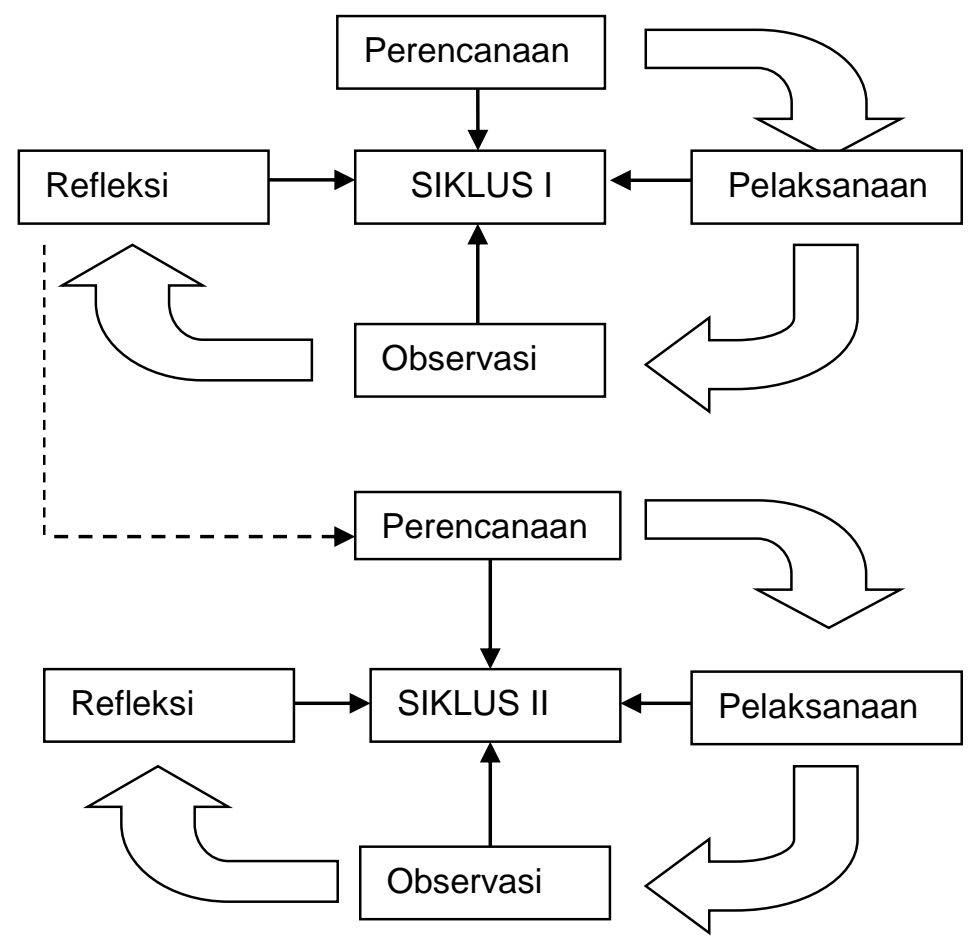

Gambar 1. Rancangan Pelaksanaan Penelitian (Arikunto, 2013)

Instrumen atau alat ukur yang gunakan dalam penelitian ini adalah instrumen lembar observasi keterlaksanaan pembelajaran (RPP). Keterampilan proses sains, tes hasil belajar kognitif. Keterlaksanaan proses pembelajaran (RPP) diamanati oleh 2 observer dan dianalisis menggunakan Persamaan 1 (Trianto, 2012).

$\mathrm{P}=\frac{X}{Y} \times 100 \%$

Dimana $\mathrm{P}=$ Persentase $\mathrm{X}=$ Jumlah yang terlaksana; dan $\mathrm{Y}=$ Total langkah yang harus dilaksanakan. Hasil pengamatan observer selanjutnya dikomversi menggunakan Tabel 1.

Tabel 1. Konversi Penskoran Tingkat Keteraksanaan Pembelajaran (Arikunto, 2013)

\begin{tabular}{ll}
\hline Keterlaksanaan (\%) & Kategori \\
\hline $80-100$ & Sangat baik \\
$65-79$ & Baik \\
$50-64$ & Kurang baik \\
$40-49$ & Tidak baik \\
$<40$ & Sangat tidak baik \\
\hline
\end{tabular}

Ketermpilan proses sains siswa diukur menggunakan instrument observasi keterampilan proses sains yang dianalisis menggunakan Persamaan 2.

$\mathrm{NP}=\frac{R}{S} \times 100 \%$ 
Dimana $\mathrm{R}=$ Jumlah skor yang nampak; $\mathrm{S}=$ Skor maksimal; dan NP = Keterampialan proses sains. Hasil penilaian ketermapilan proses sains siswa selanjutnya dikategorisasi menggunakan Tabel 2.

Tabel 2. Konversi Persentase Keterampilan Proses Sains Siswa (Arikunto, 2013)

\begin{tabular}{ll}
\hline Keterampilan proses sains $(\%)$ & Kategori \\
\hline $76-100$ & Sangat tinggi \\
$56-75$ & Tinggi \\
$40-55$ & Kurang \\
$<40$ & Rendah \\
\hline
\end{tabular}

Hasil belajar kognitif siswa diukur menggunakan instrument tes dengan 20 item soal. Hasil belajar kognitifi siswa dianalisis secara deskriptif berdasarkan ketuntasan individu dan ketuntasan klasikal. Penelitian ini dinyatakan berhasil jika ketuntasan klasikal siswa $\geq 85 \%$.

\section{HASIL PENELITIAN DAN PEMBAHASAN}

Peneitian ini menggunakan penerapan asesmen kinerja pada kegiatan praktikum biologi untuk meningkatkan keterampilan proses sains dan hasil belajar kognitif siswa yang dilaksanakan melalui 2 siklus. Data yang diperoleh adalah data kualitatif dan data kuantitatif. Data kualitatif diperoleh dari hasil observasi yang dilakukan selama pelaksanan tindakan, sedangkan data kuantitatif diperoleh dari hasil evaluasi pada akhir siklus.

\section{Keterlaksanaan Proses Pembelajaran RPP}

Hasil observasi keterlaksanaan proses pembelajaran menunjukkan adanya peningkatan dari proses pembelajaran siklus I ke proses pembelajran siklus II, hal ini sesuai dengan hasil observasi yang disajikan pada Tabel 3 dan Gambar 2.

Tabel 3. Keterlaksanaan Proses Pembelajaran Siklus I dan II

\begin{tabular}{lccccc}
\hline Siklus & Jumlah siswa & $\begin{array}{c}\text { Indikator } \\
\text { Terlaksana }\end{array}$ & $\begin{array}{c}\text { Indikator Tidak } \\
\text { Terlaksana }\end{array}$ & Persentase & Kategori \\
\hline I & 20 & 11 & 5 & $68 \%$ & Baik \\
II & 20 & 16 & 0 & $100 \%$ & Sangat baik \\
\hline
\end{tabular}

Berdasarkan Gambar 2, dapat diketahui bahwa tingkat keterlaksanaan pembelajaran dengan menggunakan Asesmen Kinerja pada siklus pertama dari 16 langkah yang direncanakan untuk pertemuan pertama hanya 11 langkah yang terlaksana sehingga persentase keterlaksanaan proses pembelajaran yang dicapai pada siklus pertama sebesar $68 \%$ dengan kategori baik sedangkan pada siklus kedua dari 15 langkah yang direncanakan, semuanya terlaksana dengan maksimal sehingga persentase keterlaksanaan proses pembelajaran pada siklus kedua ini sebesar $100 \%$ dengan kategori sangat baik.

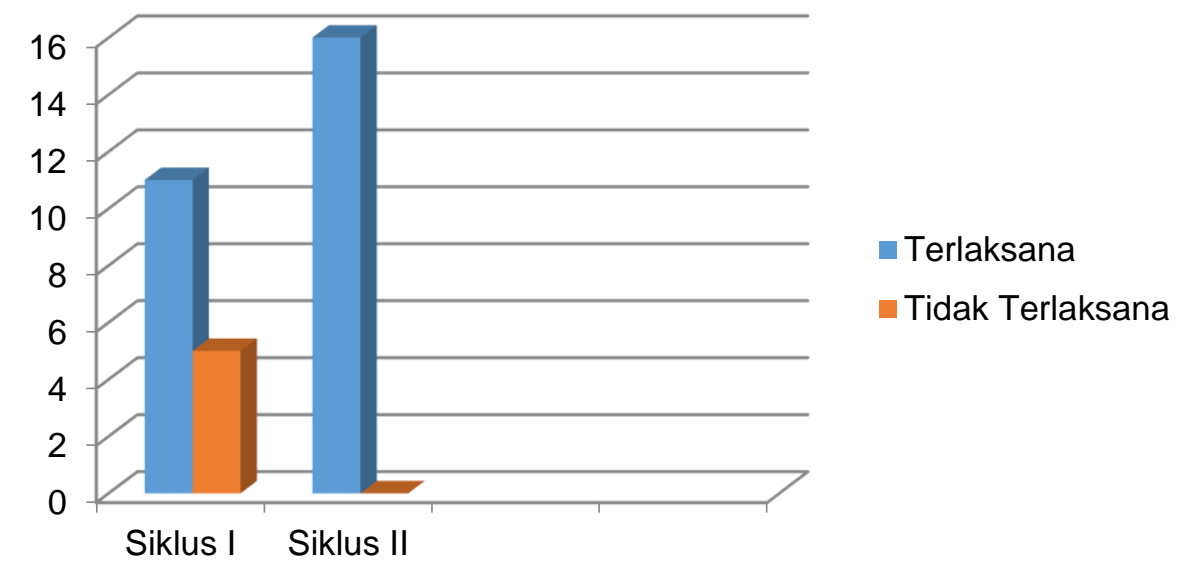

Gambar 2. Perbandingan keterlaksanaan pembelajaran siklus I dan siklus II

Hasil refleksi kegiatan pembelajaran pada siklus I ditemukan bahwa guru masih kurang memberikan stimulus-stimulus otentik untuk meningkatkan motivasi siswa. Selain itu, siswa 
pada siklus I ditemukan masih belum terbiasa dengan assessment kinerja untuk menilai keterampilan proses sains yang dimiliki sehinggi terobservasi masih tergesa-gesa dalam melaksanakan aktivitas belajar. Kedua hasil refleksi tersebut berdampak pada kurangnya partisipasi siswa dalam menyimpulkan hasil pembelajaran dan belum berani melakukan komunikasi hasil belajar dan bertanya. Kendala-kendala pada siklus I tersebut telah diperbaiki pada siklus II. Hal itu terbukti dari meningkatnya keterlaksanaan pembelajaran siswa pada siklus II. Pada pembelajaran siklus II, integrasi keterampilan-keterampilan proses yang dinilai semakin ditekankan sehingga motivasi belajar siswa dapat ditingkatkan karena hand on activity lebih diperhatikan. Sejalan dengan penelitian ini, hasil penelitian terdahulu menyatakan penekanan hand on activity terbukti dapat meningkatkan keterampilan berpikir kritis siswa pada pembelajaran fisika (Yuliati dkk., 2011). Lebih lanjut dijelaskan, proses pembelajaran yang menekankan pada integrasi keterampilan proses sains dinyatakan dapat memotivasi siswa lebih baik untuk belajar (Daud, 2018).

\section{Keterampilan Proses Sains Siswa}

Hasil analisis data mengenai keterlaksanaan proses sains siswa pada siklus I dan siklus II disajikan pada Tabel 4 dan Gambar 3.

Tabel 4. Keterampilan proses sains siklus I dan II.

\begin{tabular}{lll}
\hline Parameter & Siklus & \\
\cline { 2 - 3 } & I & II \\
\hline Jumlah skor yang nampak & 11 & 15 \\
Jumlah skor yang tidak nampak & 9 & 5 \\
Jumlah skor maksimal & 20 & 20 \\
Persentase & $55 \%$ & $75 \%$ \\
Kategori & Cukup Tinggi & Tinggi \\
\hline
\end{tabular}

Berdasarkan Gambar 3, dapat diketahui bahwa persentase keterampilan proses sains siswa pada siklus pertama adalah $55 \%$ dengan kategori cukup tinggi. Kemudian skor keterampilan proses sains siswa pada siklus kedua adalah 15 persentase keterampilan proses sains siswa untuk siklus kedua sebesar $75 \%$ dengan kategori tinggi.

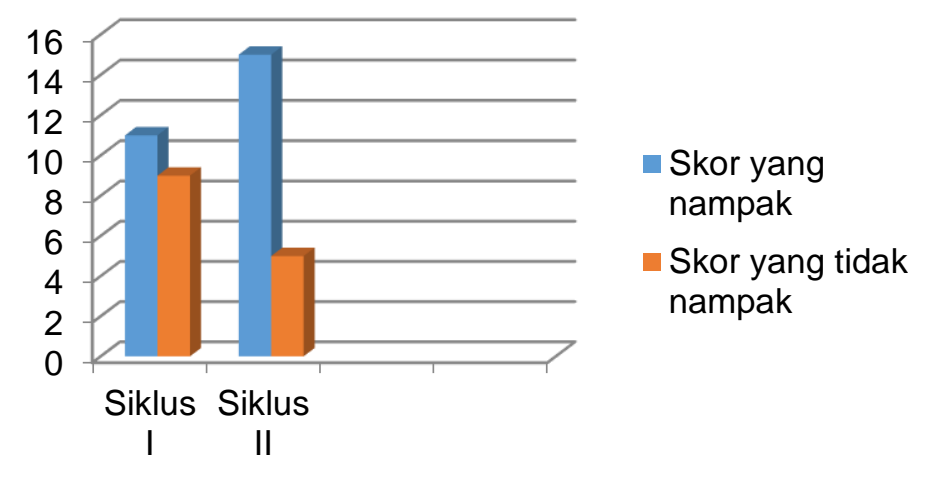

Gambar 3. Perbandingan keterampilan proses sains siswa pada siklus I dan siklus II

IImu pengetahuan alam atau sering disebut IPA/Sains secara umum memiliki tiga komponen penting yaitu produk, proses, dan sikap (Asy'ari dkk., 2019). Pada komponen proses dan sikap inilah keterampilan proses sains memiliki peranan penting untuk mencapai produk belajar (hasil belajar kognitif) yang baik (Juhji, 2016). Pernyataan tersebut sejalan dengan hasil penelitian yang menunjukkan hasil belajar kognitif siswa meningkat pada setiap siklus penelitian ini.

\section{Hasil Belajar Kognitif Siswa}

Tes dilakukan pada setiap akhir siklus dengan tujuan untuk mengukur penguasaan konsep terhadap materi yang telah disampaikan setelah menerapkan Asesmen Kinerja untuk 
mengetahui peningkatan hasil belajar siswa setiap akhir siklus. Evaluasi hasil belajar kognitif siswa pada siklus I dan siklus II disajikan pada Tabel 5 dan Gambar 4.

Tabel 5. Hasil Belajar Siklus I dan Siklus II

\begin{tabular}{lll}
\hline Parameter & \multicolumn{2}{l}{ Siklus } \\
\cline { 2 - 3 } & I & II \\
\hline Jumlah siswa yang ikut tes & 20 & 20 \\
Nilai tertinggi & 90 & 95 \\
Nilai terendah & 40 & 55 \\
Nilai rata-rata & 66 & 77 \\
Jumlah siswa yang tuntas & 8 siswa & 18 siswa \\
Jumlah siswa yang tidak tuntas & 12 siswa & 2 siswa \\
KKM & & 70 \\
Ketuntasan klasikal & $40 \%$ & $90 \%$ \\
Ketuntasan & Tidak Tuntas & Tuntas \\
\hline
\end{tabular}

Gambar 4 menunjukkan hasil belajar siswa pada setiap siklusn mengalami peningkatan. Nilai rata-rata siswa pada siklus I sebesar 66 dengan jumlah siswa yang tuntas sebanyak 8 siswa dan jumlah siswa yang tidak tuntas sebanyak 12 siswa. Dari jumlah tersebut diketahui ketuntasan klasikal sebesar $40 \%$. Persentase ketuntasan ini belum mencapai ketuntasan klasikal yang sudah ditentukan yaitu nilai $\geq 70$ sesuai dengan KKM di MTs Darul Hikmah Darek. Dengan demikian hasil belajar yang diperoleh pada siklus pertama tidak sesuai dengan apa yang diharapkan, dari analisis masalah yang ada ditemukan beberapa hal diantaranya yaitu guru tidak menyampaikan tujuan pembelajran di kelas dan guru tidak menyimpulkan hasil pembelajaran pada kegiatan penutup.

Pada siklus II diketahui bahwa ketuntasan belajar siswa secara klasikal yang tercapai adalah $90 \%$ dengan nilai rata-rata siswa sebesar 77 jumlah siswa yang tuntas 18 siswa yang belum tuntas sebanyak 2 siswa. Berdsarkan hasil evaluasi diketahui bahwa siswa yang memperoleh nilai $\geq 70$ adalah 18 siswa dan persentase ketuntasan klasikal yang diperoleh lebih dari $90 \%$. Berdasarkan hasil tersebut ditetapkan bahwa tujuan pembelajran tindakan siklus II sudah tercapai. Hasil penelitian terdahulu menunjukkan penerapan keterampilan proses sains dalam pembelajar IPA sekolah dasar dapat meningkatkan hasil belajar siswa (Acesta, 2014)

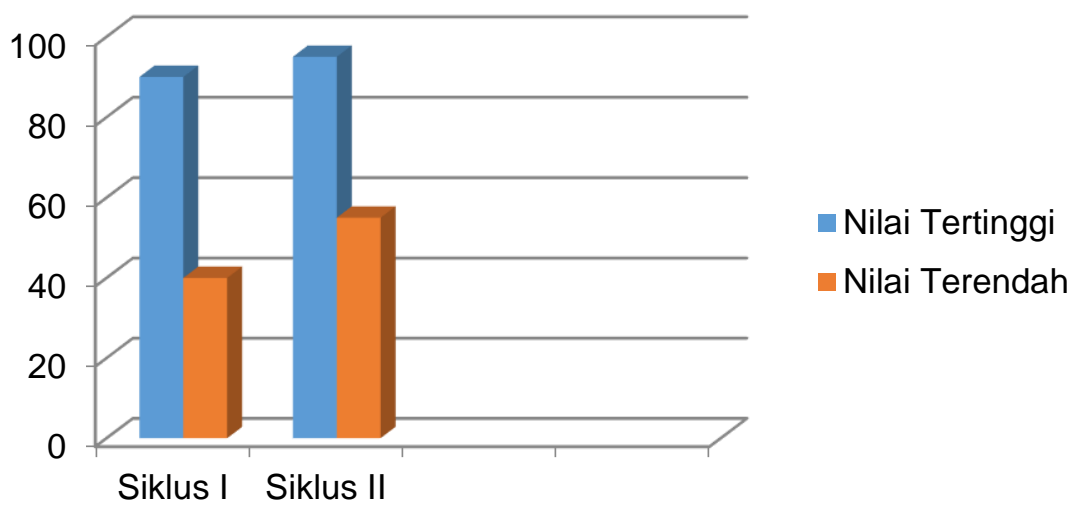

Gambar 4. Perbandingan hasil belajar kognitif siswa pada siklus I dan siklus II

Peningkatan keterampilan proses sains dan hasil belajar kognitif siswa dalam penelitian ini juga tidak terlepas dari penerapan asesmen kinerja yang diterapkan. Hasil penelitian menunjukkan keterampilan proses sains siswa berkembang seiring penerapan asesmen kinerja yang dalam penelitian tersebut menggunakan level of inquiry dengan kategori sedang (Muliyani dkk., 2017) menciptakan nuansa pembelajaran yang aktif dan selaras antar komponen kognitif, afektif, dan keterampilan (Haenilah, 2017). 


\section{KESIMPULAN}

Penerapan asesmen kinerja pada kegiatan praktikum biologi dapat meningkatkan keterampilan proses sains dan hasil belajar kognitif siswa kelas VII MTs Darul Hikmah Darek Tahun Pelajaran 2015/2016. Hal ini dapat dilihat dari perolehan persentase keterampilan proses sains siswa pada siklus I yaitu 55\% dengan kategori cukup tinggi, meningkat pada siklus II meningkat menjadi 75\% dengan kategori tinggi. Perolehan skor rata-rata hasil belajr kognitif siswa pada siklus I yaitu 66 dengan ketuntasan klasikal 40\% dan siklus II meningkat menjadi 77 , dengan ketuntasan klasikal meningkat menjadi $90 \%$.

\section{SARAN}

Guru diharapkan dapat memberikan arahan dan bimbingan serta kreatif mendesain metode pembelajaran asesmen kinerja menjadi lebih menarik sehingga siswa dapat meraih prestasi belajar yang maksimal dan mampu membekali siswa untuk menerapkan metode pembelajaran asesmen kinerja dalam kehidupan sehari-hari. Untuk penelitian selanjutnya, penelitian tentang penerapan asesmen kinerja diharapkan dapat dilaksanakan pada pembelajaran atau pada pokok bahasan lain.

\section{UCAPAN TERIMAKASIH}

Penelitian ini tidak menerima hibah khusus dari agensi pendanaan mana pun di sektor publik, komersial, atau nirlaba.

\section{DAFTAR PUSTAKA}

Acesta, A. (2014). Penerapan pendekatan keterampilan proses sains untuk meningkatkan hasil belajar siswa dalam pembelajaran ipa. Jurnal IImiah Pendidikan Dasar, 1(2), 96106. https://doi.org/10.30659/pendas.1.2.\%p

Am, Z. (2018). Teknik penilaian hasil pembelajaran. Rausyan Fikr: Jurnal Pemikiran Dan Pencerahan, 14(02), Article 02. https://doi.org/10.31000/rf.v14i02.901

Amrulloh, M. A. (2015). Sistem Penilaian dalam Pembelajaran. Jurnal Al Bayan: Jurnal Jurusan Pendidikan Bahasa Arab, 7(2), 125-148. https://doi.org/10.24042/albayan.v7i2.350

Arikunto, S. (2013). Dasar-dasar Evaluasi Pendidikan (edisi 2). Bumi Aksara. https://ecampusfip.umj.ac.id/pustaka_umj/main/item/14939

Asy'ari, M., \& Fitriani, H. (2017). Literatur Reviu Keterampilan Proses Sains sebagai Dasar Pengembangan Keterampilan Berpikir Tingkat Tinggi. Prisma Sains : Jurnal Pengkajian IImu dan Pembelajaran Matematika dan IPA IKIP Mataram, 5(1), 1. https://doi.org/10.33394/j-ps.v5i1.1114

Asy'ari, M., Fitriani, H., Zubaidah, S., \& Mahanal, S. (2019). The Science Process Skills of Prospective Biology Teachers in Plant Cell Material Based on Gender. International Journal of Emerging Technologies in Learning (iJET), 14(19), 168. https://doi.org/10.3991/ijet.v14i19.11208

Daud, M. (2018). Efektivitas pembelajaran keterampilan proses sains (kps) pada pokok bahasan termo kimia dalam meningkatkan kemampuan siswa di sma negeri 1 Krueng Barona Jaya kabupaten Aceh Besar dinas pendidikan Aceh. Lantanida Journal, 6(1), 90-102. https://doi.org/10.22373/lj.v6i1.3157

Gürses, A., Çetinkaya, S., Doğar, Ç., \& Şahin, E. (2015). Determination of Levels of Use of Basic Process Skills of High School Students. Procedia - Social and Behavioral Sciences, 191, 644-650. https://doi.org/10.1016/j.sbspro.2015.04.243

Hadiana, D. (2015). Penilaian Hasil Belajar untuk Siswa Sekolah Dasar. Jurnal Pendidikan dan Kebudayaan, 21(1), 15-26. https://doi.org/10.24832/jpnk.v21i1.173

Haenilah, E. Y. (2017). Efektivitas desain pembelajaran terpadu berbasis core content di sekolah dasar. Sekolah Dasar: Kajian Teori Dan Praktik Pendidikan, 26(1), 39-48. https://doi.org/10.17977/um009v26i12017p039

Juhji, J. (2016). Peningkatan keterampilan proses sains siswa melalui pendekatan inkuiri terbimbing. Jurnal Penelitian dan Pembelajaran IPA, 2(1), 58-70. 
Kemendikbud. (2013). Peraturan Menteri Pendidikan dan Kebudayaan Republik Indonesia Nomor $54 \quad$ Tahun $2013 . \quad$ https://akhmadsudrajat.files.wordpress.com/2013/06/01-b-salinan-lampiranpermendikbud-no-54-tahun-2013-ttg-skl.pdf

Martin, M. O., Mullis, I. V. S., Foy, P., Stanco, G. M., International Association for the Evaluation of Educational Achievement, \& Trends in International Mathematics and Science Study (Ed.). (2012). TIMSS 2011 international results in science. IEA, TIMSS \& PIRLS, International Study Center, Lynch School of Education, Boston College.

Muhali, M. (2019). Pembelajaran Inovatif Abad Ke-21. Jurnal Penelitian dan Pengkajian IImu Pendidikan: e-Saintika, 3(2), 25-50. https://doi.org/10.36312/e-saintika.v3i2.126

Muliyani, R., Kurniawan, Y., \& Sandra, D. A. (2017). Peningkatan Keterampilan Proses Sains Terpadu Siswa melalui Implementasi Levels of Inquiry (Lol). Tadris: Jurnal Keguruan dan IImu Tarbiyah, 2(2), 81-86. https://doi.org/10.24042/tadris.v2i2.1904

Mulyasa, E. \& Mukhlis. (2007). Standar kompetensi dan sertifikasi guru. Remaja Rosdakarya. Nur, M. (2011). Modul Keterampilan-keterampilan Proses dan Hakikat Sains. PSMS Unesa.

OCED. (2016). Country Note - Results from PISA 2015 [Report]. https://www.oecd.org/pisa/PISA-2015-Indonesia.pdf

Rustaman, N. (2005). Strategi belajar mengajar biologi. UM Press.

Setyowati, A., Subali, B., \& Mosik -. (2011). Implementasi Pendekatan Konflik Kognitif Dalam Pembelajaran Fisika Untuk Menumbuhkan Kemampuan Berpikir Kritis Siswa Smp Kelas Viii. Jurnal Pendidikan Fisika Indonesia, 7(2), Article 2. https://doi.org/10.15294/jpfi.v7i2.1078

Trianto. (2012). Model Pembelajaran Terpadu: Konsep, strategi, dan implementasinya dalam Kurikulum Tingkat Satuan Pendidikan (KTSP). Bumi Aksara. //library.fis.uny.ac.id\%2Fopac\%2Findex.php\%3Fp\%3Dshow_detail\%26id\%3D1227\%2 6 keywords\%3D

Verawati, N. N. S. V., Prayogi, S., \& Asy'ari, M. (2014). Reviu literatur tentang keterampilan proses sains. Lensa: Jurnal Kependidikan Fisika, 2(1), 194. https://doi.org/10.33394/jIkf.v2i1.310

Widodo, A., Wuryastuti, S., \& Margaretha. (2010). Pendidikan IPA di Sekolah Dasar. UPI Press.

Yuliati, D. I., Yulianti, D., \& Khanafiyah, S. (2011). Pembelajaran Fisika Berbasis Hands On Activities Untuk Menumbuhkan Kemampuan Berpikir Kritis Dan Meningkatkan Hasil Belajar Siswa Smp. Jurnal Pendidikan Fisika Indonesia, 7(1), Article 1. https://doi.org/10.15294/jpfi.v7i1.1064 